\title{
Insights into binding of S100 proteins to scavenger receptors: class B scavenger receptor CD36 binds S100A12 with high affinity
}

\author{
Christoph Tondera $^{1,2} \cdot$ Markus Laube $^{1} \cdot$ Jens Pietzsch $^{1,2}$
}

Received: 13 June 2016 / Accepted: 6 October 2016 / Published online: 12 October 2016

(c) The Author(s) 2016. This article is published with open access at Springerlink.com

\begin{abstract}
The EF-hand type calcium-binding protein S100A12 exerts numerous intra- and extracellular functions of (patho)physiological relevance. Therefore, receptors of S100A12 are of high interest for research and clinical applications. Beside the extensively studied receptor for advanced glycation endproducts (RAGE), G-protein coupled receptors and more recently, scavenger receptors are suggested to be putative S100A12 receptors. Own findings and further information from the literature predestined CD36, a class B scavenger receptor, as promising candidate. To substantiate or prove against this hypothesis, this study aimed at investigation of interaction of S100A12 and CD36 on molecular and cellular level by the use of surface plasmon resonance (SPR), radio- and fluorescence-tracer-based cell binding, and cell activation experiments. S100A12 revealed binding affinity to CD36 in the low nanomolar range, essentially, at the CD36 thrombospondin-1 binding site. Additionally, S100A12-mediated translocation of CD36 to the membrane and elevation of both CD36 and peroxisome proliferator-activated receptor $\gamma$ (PPAR $\gamma$ ) expression was observed, which suggest a potential regulatory function of S100A12-CD36 interaction.
\end{abstract}

Handling Editor: S. L. Parker.

Electronic supplementary material The online version of this article (doi:10.1007/s00726-016-2349-2) contains supplementary material, which is available to authorized users.

Jens Pietzsch

j.pietzsch@hzdr.de

1 Department of Radiopharmaceutical and Chemical Biology, Institute of Radiopharmaceutical Cancer Research, Helmholtz-Zentrum Dresden-Rossendorf, Dresden, Germany

2 Department of Chemistry and Food Chemistry, Technische Universität Dresden, Dresden, Germany
Keywords EF-hand calcium-binding proteins $\cdot$ Surface plasmon resonance Pattern recognition receptors Damage-associated molecular patterns $\cdot$ Receptor for advanced glycation endproducts (RAGE)

$\begin{array}{ll}\text { Abbreviations } \\ {\left[{ }^{18} \mathrm{~F}\right] \mathrm{FB}} & 4-\left[{ }^{18} \mathrm{~F}\right] \text { fluorobenzoyl- } \\ {\left[{ }^{18} \mathrm{~F}\right] \mathrm{SFB}} & N \text {-succinimidyl-4- }\left[{ }^{18} \mathrm{~F}\right] \text { fluorobenzoate } \\ \text { BCA } & \text { Bicinchoninic acid } \\ \text { BSA } & \text { Bovine serum albumin } \\ \text { CHO } & \text { Chinese hamster ovary } \\ \text { EDC } & \text { 1-Ethyl-3-(3-dimethylaminopropyl) } \\ & \text { carbodiimide } \\ \text { GST } & \text { Glutathione } S \text {-transferase } \\ \text { HEPES } & \text { 2-[4-(2-hydroxyethyl)piperazin-1-yl]ethanesul- } \\ & \text { fonic acid } \\ \text { HBS } & \text { HEPES buffered saline } \\ \text { IPTG } & \text { Isopropyl- } \beta \text {-D-1-thiogalactopyranoside } \\ \text { LDL } & \text { Low density lipoprotein } \\ \text { LOX } & \text { Lectin-like oxidized low density lipoprotein } \\ & \text { (LDL) receptor } \\ \text { malBSA } & \text { Maleylated bovine serum albumin } \\ \text { NHS } & N \text {-hydroxysuccinimide } \\ \text { PBS } & \text { Phosphate buffered saline } \\ \text { POD } & \text { Peroxidase } \\ \text { PPAR } & \text { Peroxisome proliferator-activated receptor } \\ \text { RAGE } & \text { Receptor for advanced glycation endproducts } \\ \text { SDS } & \text { Sodium dodecyl sulfate } \\ \text { SPR } & \text { Surface plasmon resonance } \\ & \end{array}$

\section{Introduction}

$\mathrm{S} 100 \mathrm{~A} 12$ is a member of the $\mathrm{S} 100$ protein family comprising more than 20 calcium-binding proteins of the EF-hand 
type. Most of them are small (molecular weight $<13 \mathrm{kDa}$ ) distinctly homoacidic proteins (Donato et al. 2013), which regulate numerous intracellular and/or extracellular functions, including activation of enzymes, maintenance of calcium homeostasis, interaction with cytoskeletal components, and interaction with receptors (Vogl et al. 1999; Hatakeyama et al. 2004; Donato et al. 2013). Once released into the extracellular space or the circulating blood, mostly by granulocytes, S100A12 in a cytokine-like manner exerts proinflammatory effects, e.g., in lymphocytes, macrophages, mast cells, endothelial cells, and neurons (Mikkelsen et al. 2001; Yang et al. 2001, 2007; Pietzsch and Hoppmann 2009). Consequently, dysregulation in S100A12 secretion is found in many pathological situations like atherosclerosis, diabetes, chronic inflammatory disorders, and cancer (Kosaki et al. 2004; Salama et al. 2008; Mori et al. 2009; Pietzsch and Hoppmann 2009; Donato et al. 2013). The most extensively studied interaction partner of extracellular S100A12 is the proinflammatory receptor for advanced glycation endproducts (RAGE) (Hofmann et al. 1999; Leclerc et al. 2009; Hoppmann et al. 2010). In vitro findings in mast cells that did not show RAGE synthesis provided evidence on putative G-protein coupled S100 receptors (Yan et al. 2008). Moreover, in vitro experiments with endothelial cells and macrophages and in vivo experiments in rats using ${ }^{18} \mathrm{~F}$-radiolabeled S100A12 provided first evidence that S100A12 also binds to scavenger receptors as demonstrated by us (Hoppmann et al. 2010). In this former study, scavenger receptor binding of S100A12 could be substantially blocked by maleylated bovine serum albumin (malBSA), a pan-scavenger receptor ligand, but not by polyinosinic acid and fucoidan, two class A scavenger receptor ligands (Acton et al. 1994; Platt et al. 1996; Fyrnys et al. 1997; Hsu et al. 2001; Thelen et al. 2010; Hoppmann et al. 2010; Yu et al. 2012). Of importance, malBSA binds to scavenger receptors of class A (SR-A1, SR-A2), class B (CD36), and the lectin-like oxidized low density lipoprotein (LDL) receptor-1 (LOX-1) (Sawamura et al. 2000; Mehta and Li 2002). This finding and further information from the literature predestined CD36 to be a strong candidate as S100A12-recognizing receptor of the scavenger receptor family. CD36 is a membrane receptor that is present on platelets, macrophages, monocytes, adipocytes, hepatocytes, myocytes, and some epithelial cells (Silverstein and Febbraio 2009). In monocytes and macrophages, CD36 acts as receptor and transporter for bioactive lipids leading to the activation of the peroxisome proliferator-activated receptor $\gamma$ (PPAR $\gamma$ ) signaling pathway, which subsequently regulates glucose metabolism and free fatty acid uptake (Tontonoz et al. 1998; Koonen et al. 2005; Graessler et al. 2007). It has to be considered that RAGE and certain scavenger receptors share a common ligand recognition principle based on electrostatic interactions between the positively charged receptor surface domains and negatively charged ligands (Adachi and Tsujimoto 2006; Jimenez-Dalmaroni et al. 2009; Gao et al. 2010; Fritz 2011). In this regard, there is an experimental evidence that well-characterized RAGE-ligands, such as advanced glycation endproducts, hypochlorite-modified proteins/apolipoproteins, and amyloid- $\beta$, also bind to CD36 (Ohgami et al. 2001; Kopprasch et al. 2004; Marsche et al. 2007; Jones et al. 2013). Another important property RAGE and CD36 have in common is the activation of signaling cascades (Goyette et al. 2009; Park 2014). This distinguishes CD36 from other scavenger receptors, e.g., those of class A. Additionally, S100A12 and CD36 are expressed in similar cell types, and more interestingly, the dysregulation of S100A12 and CD36 is related to similar pathological outcomes like atherosclerosis (Goyette et al. 2009; Park 2014).

To check the hypothesis that CD36 is a putative S100A12 receptor, this study aimed to investigate the possible interaction of S100A12 and CD36 on molecular and cellular level by the use of surface plasmon resonance (SPR), cell association and cell activation experiments.

\section{Methods}

\section{Cell lines}

Chinese hamster ovary (CHO)-K1 and CHO-CD36 cells were purchased from ATCC. CHO-RAGE cells were generated as described elsewhere (Hoppmann et al. 2010). Briefly, the vector pDNR-LIB-flRAGE was cloned into the eukaryotic expression vector pIRES-AcGFP1. For amplification, the vector was transfected into E. coli Top10 and positive clones were selected using $50 \mu \mathrm{g} / \mathrm{mL}$ kanamycin. Positive clones were checked for success of cloning and transfection using colony-PCR and sequencing analyses (Agowa $\mathrm{GmbH})$. Transfection of plasmid-DNA into CHO-cells was performed using Lipofectamine 2000. Transfection was performed in serum free medium with $1 \mu \mathrm{g}$ of plasmid-DNA and for $6-8 \mathrm{~h}$ at $37{ }^{\circ} \mathrm{C}$ under normal cell culture conditions $\left(5 \% \mathrm{CO}_{2}\right.$, v/v). Subsequently, cells were incubated in serum containing medium with selected antibiotics ( $300 \mu \mathrm{g} / \mathrm{mL}$ G418 and $250 \mu \mathrm{g} / \mathrm{mL}$ Zeocin). The success of transfection of CHO-RAGE cells was checked using fluorescence microscopy, Western blot analyses and flow cytometry.

\section{Immunocytochemical analysis}

Synthesis of CD36 and RAGE was detected by immunocytochemical staining. Therefore, cells were fixed with $4 \%(\mathrm{w} / \mathrm{v})$ paraformaldehyde and $2.5 \%(\mathrm{w} / \mathrm{v})$ sucrose in phosphate buffered saline (PBS). After permeabilization 
with $0.3 \%(\mathrm{v} / \mathrm{v})$ Triton-X-100 in PBS, unspecific binding sites were blocked with a blocking solution containing $5 \%$ $(\mathrm{w} / \mathrm{v})$ bovine serum albumin (BSA) and $0.5 \%(\mathrm{v} / \mathrm{v})$ Tween 20 in PBS. For antibody staining, the monoclonal antiCD36 antibody [FA6-152] (abcam17044, 1:50) and the polyclonal anti-RAGE antibody (R\&D systems, AF-1145 1:50) as well as secondary antibodies, anti-mouse AlexaFluor $488^{\circledR}$ (for anti-CD36 antibody) and anti-goat AlexaFluor594 ${ }^{\circledR}$ (for anti-RAGE antibody) were used. Counterstaining was conducted using the cell DNA marker Hoechst $33258(5 \mu \mathrm{g} / \mathrm{mL})$. Images were acquired using the confocal laser-scanning microscope IX83 (Olympus).

\section{Western blot analysis}

Western blot analyses were performed as published elsewhere (Wolf et al. 2011). In short, sodium dodecyl sulfatepolyacrylamide electrophoresis of cell lysates with following semidry Western blotting was performed. Blots were blocked using blocking solution containing $5 \%(\mathrm{w} / \mathrm{v})$ dry milk powder, $2 \%(\mathrm{w} / \mathrm{v})$ BSA and $0.05 \%(\mathrm{v} / \mathrm{v})$ Tween 20 in Tris-buffered saline. For antibody staining, the monoclonal anti-CD36 antibody [FA6-152] (abcam17044, 1:500) and the polyclonal anti-RAGE antibody (R\&D systems, AF-1145 1:500) as well as the peroxidase (POD) coupled secondary antibodies (anti-mouse IgG-POD for anti-CD36 antibody and anti-goat IgG-POD for anti-RAGE antibody) were used. Images were acquired using the Super Signal Dura and Pico kit (Thermo Scientific). Western blots were obtained from two experimental settings: (a) lysates were obtained from cells grown in cell culture medium supplemented with $10 \%$ fetal calf serum, (b) for cell activation studies lysates were obtained from cells after incubation for 90 min with serum-free calcium binding buffer $(20 \mathrm{mM}$ 2-[4-(2-hydroxyethyl)piperazin-1-yl]ethanesulfonic acid (HEPES), $150 \mathrm{mM} \mathrm{NaCl}, 1.2 \mathrm{mM} \mathrm{MgCl} 2,1.3 \mathrm{mM} \mathrm{CaCl}_{2}$; $\mathrm{pH} 7.5)$.

\section{Recombinant S100A12 synthesis}

Recombinant expression and purification of S100A12 (rS100A12) was performed as published elsewhere (Hoppmann et al. 2008). Briefly, pGEX-S100A12 transformed E.coli BL21 was cultivated in LB medium supplemented with $50 \mu \mathrm{g} / \mathrm{mL}$ ampicillin at $37{ }^{\circ} \mathrm{C}$ with shaking. When optical density $(600 \mathrm{~nm})$ of 1.0 was reached, protein expression was induced by adding $0.5 \mathrm{mmol} / \mathrm{L}$ isopropyl$\beta$-D-1-thiogalactopyranoside (IPTG) for $4 \mathrm{~h}$ at $25{ }^{\circ} \mathrm{C}$. The cell pellet was lysed using $20 \%(\mathrm{v} / \mathrm{v})$ Triton X-100, $4000 \mathrm{U} / \mathrm{mL}$ lysozyme, $25 \mathrm{U} / \mathrm{mL}$ benzonase and ultrasound. RS100A12 protein was purified using glutathionesepharose. Glutathione $S$-transferase (GST) free proteins were eluted using PreScission ${ }^{\mathrm{TM}}$ protease (GE Healthcare).
Further purification was performed using size exclusion chromatography. The purified protein was analyzed by mass spectrometry and Western blot (polyclonal goat antihEN-RAGE/S100A12, R\&D Systems, AF1052). After snap freezing in liquid nitrogen, the purified protein was stored at $-65{ }^{\circ} \mathrm{C}$ until usage for further experiments. Furthermore, commercially available native human S100A12 protein (nS100A12) was obtained from Life Technologies with the reference number 11143-HNAE-50. Compared to the purchased native nS100A12 the recombinant synthesized protein rS100A12 possesses five additional $N$-terminal amino acids (GPLGS) (Hoppmann et al. 2008).

\section{Fluorescence- and radiolabeling of recombinant rS100A12}

Radiolabeling of rS100A12 with $\mathrm{N}$-succinimidyl $4-\left[{ }^{18} \mathrm{~F}\right]$ fluorobenzoate $\left(\left[{ }^{18} \mathrm{~F}\right] \mathrm{SFB}\right)$ was performed as published by us earlier for the investigation of the interaction of S100A12 and RAGE (Hoppmann et al. 2008, 2010). Briefly, $\left[{ }^{18} \mathrm{~F}\right] \mathrm{SFB}$ diluted in acetonitrile was directly added to the rS100A12 solution in PBS and incubated for $30 \mathrm{~min}$ at $37{ }^{\circ} \mathrm{C}$. The radiolabeled $4-\left[{ }^{18} \mathrm{~F}\right]$ fluorobenzoyl- $\left(\left[{ }^{18} \mathrm{~F}\right] \mathrm{FB}\right)$ rS100A12 was purified using a HiTrap desalting column (GE Healthcare) with the ÄKTAprime ${ }^{\circledR}$ plus (GE Healthcare) chromatography system. The activity of the product was determined using the ISOMED 2000 calibrator (Nuklear-Medizintechnik Dresden $\mathrm{GmbH}$ ).

To obtain a second, labeled S100A12 protein species, as independent marker for cell binding experiments and SPR studies (as described below), fluorescein-labeled rS100A12 was synthesized. Therefore, $N$-hydroxysuccinimide-fluorescein [(NHS)-fluorescein, Thermo Scientific] was used by following the manufacturer's instruction. Briefly, $1 \mathrm{mg}$ of $\mathrm{rS100A12},(M=10,974 \mathrm{~g} / \mathrm{mol}, c=1 \mathrm{mg} / \mathrm{mL})$ in borate buffer ( $\mathrm{pH}$ 8.0) was reacted with 15 times molar excess of NHS-fluorescein $(M=473.4 \mathrm{~g} / \mathrm{mol}, c=10 \mathrm{mg} / \mathrm{mL})$ for $1 \mathrm{~h}$ at room temperature. Purification of the fluoresceinrS100A12 was performed in Slide-A-Lyzer ${ }^{\mathrm{TM}}$ dialysis cassettes (Thermo Fisher) with an exclusion size of $M<7000 \mathrm{~g} /$ mol. Depending on the following study PBS or calcium binding buffer (20 mM 2-[4-(2-hydroxyethyl)piperazin1-yl]ethanesulfonic acid (HEPES), $150 \mathrm{mM} \mathrm{NaCl}, 1.2 \mathrm{mM}$ $\mathrm{MgCl}_{2}, 1.3 \mathrm{mM} \mathrm{CaCl}_{2} ; \mathrm{pH} 7.5$ ) were used.

\section{Cell binding experiments}

To quantify the amount of $\left[{ }^{18} \mathrm{~F}\right] \mathrm{FB}-\mathrm{rS} 100 \mathrm{~A} 12$ binding cells were incubated with $\left[{ }^{18} \mathrm{~F}\right] \mathrm{FB}-\mathrm{rS} 100 \mathrm{~A} 12$ in $\mathrm{PBS}++$ for $90 \mathrm{~min}$ at $37{ }^{\circ} \mathrm{C}$. For blocking, a 15-fold excess of rS100A12 related to $\left[{ }^{18} \mathrm{~F}\right] \mathrm{FB}-\mathrm{rS} 100 \mathrm{~A} 12$ or the monoclonal anti-CD36 antibody (FA6-152, abcam, $c=10 \mathrm{mg} /$ $\mathrm{mL}$ ) (Olivetta et al. 2014; Wang et al. 2014) was added to 
the cells $20 \mathrm{~min}$ at room temperature before starting the binding experiment. After incubation cells were lysed with $\mathrm{NaOH}(0.1 \mathrm{M})$ and sodium dodecyl sulfate (SDS) [1\% $(\mathrm{w} / \mathrm{v})]$. Activity was quantified using the gamma counter COBRA $^{\mathrm{TM}}$ II. Obtained activity values were put in relation to the starting activity (\% ID) and the amount of protein in the cell lysate. Protein determination was performed using the Pierce ${ }^{\circledR}$ bicinchoninic acid (BCA) Protein Assay (Thermo Scientific) following the manufacturer's instruction. The amount of cellular fluorescein-rS100A12 binding was determined similar to the $\left[{ }^{18} \mathrm{~F}\right] \mathrm{FB}-\mathrm{rS} 100 \mathrm{~A} 12$ experiments. Cells were grown in 24 -well plates to $80 \%$ confluence. Cells were incubated with $200 \mu \mathrm{L}$ of incubation solution for $90 \mathrm{~min}$ at $37^{\circ} \mathrm{C}$. For antibody blocking experiments, the monoclonal anti-CD36 antibody (FA6-152, abcam) was added to the cells for $30 \mathrm{~min}$ at $37^{\circ} \mathrm{C}$ in a concentration of $10 \mu \mathrm{g} / \mathrm{mL}$ before starting the cell binding experiment. Afterwards, cells were lysed with sodium hydroxide $(\mathrm{NaOH}$, $0.1 \mathrm{M})$ and SDS [1 \% (w/v)]. Fluorescence signal quantification was checked with assays using cell lysates using the Synergy ${ }^{\mathrm{TM}} 4$ Multi-Mode Microplate Reader (BioTek) with $\lambda_{\mathrm{Ex}}=485 \mathrm{~nm}, \lambda_{\mathrm{Em}}=525 \mathrm{~nm}$ as filter setting. Obtained relative fluorescence units were put in relation to the amount of protein in the cell lysate. Protein determination was performed using the Pierce ${ }^{\circledR}$ BCA Protein Assay (Thermo Scientific) following the manufacturer's instruction.

\section{Surface plasmon resonance}

The SPR analyses were performed using a Biacore T100 (GE Healthcare). The ligand, CD36 (His-tagged recombinant human protein, Sino Biological, Life technologies, 70-80 kDa), was immobilized on a $\mathrm{C} 1$ sensor chip using the amine coupling kit (GE Healthcare) and PBS (GE Healthcare). The employed $\mathrm{C} 1$ amine coupling procedure comprises a surface cleaning step using a solution of $0.03 \%(\mathrm{v} / \mathrm{v})$ Triton $\mathrm{T} 100$ in $100 \mathrm{mM}$ glycine ( $\mathrm{pH}$ 12.3), the surface activation by 1-ethyl-3-(3-dimethylaminopropyl) carbodiimide (EDC)/NHS, the coupling step using a solution of CD36 at a concentration of $20 \mu \mathrm{g} / \mathrm{mL}$ in $10 \mathrm{mM}$ acetate buffer $(\mathrm{pH} 4)$, and the blocking of the surface using ethanolamine. Afterwards $1000 \mathrm{RU}$ of CD36 was immobilized on the sensor surface. A reference cell was prepared by blank immobilization. $350 \mu \mathrm{M} \mathrm{CaCl}{ }_{2}$ in HEPES buffered saline (HBS)-P + buffer (GE Healthcare) was sterile filtered and used for further SPR experiments. Kinetic data were obtained by a single cycle kinetic using the respective S100A12 species rS100A12 and nS100A12 in concentrations of $0.62,1.85,5.56,16.67$, and $50.0 \mathrm{nM}$. The analyte was injected over the two flow cells at a flow rate of $30 \mu \mathrm{L} /$ min and at a temperature of $25{ }^{\circ} \mathrm{C}$. The association and dissociation time was 90 and $900 \mathrm{~s}$, respectively. The surfaces were regenerated by a sequence of glycine $(10 \mathrm{mM}, \mathrm{pH}$
$1.5,5 \mathrm{~s})$ and $\mathrm{NaOH}(0.05 \mathrm{mM}, 5 \mathrm{~s})$ followed by a stabilization period of $300 \mathrm{~s}$. Starting from the respective solution of $\mathrm{r} / \mathrm{nS} 100 \mathrm{~A} 12$, six $50 \mathrm{nM}$ stock solutions were prepared which were further diluted in triplicate to yield the given final concentrations of the analyte. A buffer blank run was performed at the beginning and the end of each sequence comprising nine single cycle kinetics with $\mathrm{r} / \mathrm{nS} 100 \mathrm{~A} 12$. Data were collected at a rate of $10 \mathrm{~Hz}$. The data were fitted to a two-state reaction model including reference subtraction and blank buffer correction derived from both blank runs using the Biacore Evaluation software 2.0.4.

\section{Cell activation experiments}

Cells were grown in $100 \mathrm{~mm}$ petri dishes or chamber slides to $80 \%$ confluence. After short washing with PBS, cells were incubated with $2 \%$ (w/v) BSA in calcium binding buffer for $1 \mathrm{~h}$ at $37^{\circ} \mathrm{C}$. Afterwards, incubation with $5 \mu \mathrm{M}$ endotoxin free rS100A12 in calcium binding buffer or with calcium binding buffer alone, as negative control, was performed for $90 \mathrm{~min}$ at $37{ }^{\circ} \mathrm{C}$. Cells were lysed for Western blot analysis or fixed using $4 \%$ (w/v) paraformaldehyde for immunocytochemical staining. Western blot analysis of PPAR $\gamma$ synthesis was performed using a monoclonal antibody (abcam191407). Additionally, Western blot analyses of tyrosine kinases Fyn (\#4023, cell signalling), pFyn (ab53690, abcam), Lyn (\#2796, cell signalling), pLyn (ab33914, abcam) and mitogen-activated kinase p38 (ab4822, abcam) were performed.

\section{Statistical analysis}

Statistical significance of all cell-binding experiments and SPR experiments was calculated using a one-way ANOVA followed by a Bonferroni post hoc test for the column analysis with Prism6 (GraphPad Software). Statistical significance was assumed for $p<0.05$ and $p<0.01$.

\section{Results}

\section{CHO cell lines expressing CD36 and RAGE}

Immunocytochemistry (Fig. 1a) and Western blot analyses (Figs. 1b, S1a) revealed the specific synthesis of the two receptors of interest by the different $\mathrm{CHO}$ cell lines. CHO$\mathrm{K} 1$ showed no synthesis of RAGE in Western blot and immunocytochemistry. A very low synthesis of CD36 could be observed for the CHO-K1 cells. The CD36 synthesis could also be observed in an even smaller amount for the CHO-RAGE cells. On the other hand, the CHO-CD36 cell lines showed very high synthesis of CD36 in immunocytochemical images and with Western blot. Immunostaining 
for RAGE revealed that only the CHO-RAGE cell line showed synthesis of RAGE.

\section{Cell binding experiments}

In Fig. 2a the cell binding of $\left[{ }^{18} \mathrm{~F}\right] \mathrm{FB}-\mathrm{rS} 100 \mathrm{~A} 12$ to the $\mathrm{CHO}$ cell lines at $37{ }^{\circ} \mathrm{C}$ is shown. Compared to CHO-K1 cells, cell association of $\left[{ }^{18} \mathrm{~F}\right] \mathrm{FB}-\mathrm{rS} 100 \mathrm{~A} 12$ was significantly higher by $40 \%$ in CHO-RAGE cells and by $20 \%$ in CHO-CD36 cells. On the other hand, using the CD36specific antibody (FA6-152) binding of $\left[{ }^{18} \mathrm{~F}\right] \mathrm{FB}-\mathrm{S} 100 \mathrm{~A} 12$ to CHO-CD36 cells could be substantially blocked. Therefore, a specific binding of $\left[{ }^{18} \mathrm{~F}\right] \mathrm{FB}-\mathrm{S} 100 \mathrm{~A} 12$ to $\mathrm{CD} 36$ could be confirmed. The fact that $\left[{ }^{18} \mathrm{~F}\right] \mathrm{FB}-\mathrm{rS} 100 \mathrm{~A} 12$ was blocked by unlabeled rS100A12 indicates a similar binding behavior of both the unlabeled and the labeled species.

As independent marker for cell binding fluorescein labeled S100A12 was used. Therefore, experiments were performed with $10 \mu \mathrm{M}$ of fluorescein-S100A12. Compared to $\mathrm{CHO}-\mathrm{K} 1$ cells, binding was significantly higher by $50 \%$ in CHO-RAGE and by $30 \%$ in CHO-CD36 cells (Fig. 2b). Using a specific monoclonal blocking antibody (FA6-152) against $\mathrm{CD} 36$, binding to $\mathrm{CHO}-\mathrm{CD} 36$ cells was reduced by $40 \%$ compared to the non-blocked situation which indicates the specificity of the interaction.

\section{SPR analyses}

SPR analyses were performed to characterize binding of S100A12 to CD36 at the protein-protein interaction level. Human recombinant CD36 (Life Technologies, reference number 10752-H08H-50, His Tag, active) was chosen as ligand and immobilized on the sensor surface by EDC/NHS amine coupling chemistry. A blank immobilized sensor surface served as reference cell to account for non-specific binding effects. Recombinant rS100A12, commercially available human, untagged recombinant nS100A12, and fluorescein-labeled rS100A12 were used as ligands. Experiments were performed as single cycle kinetics and analytes were used in a concentration range of $0.62-50.0 \mathrm{nM}$ (Fig. 3a). $K_{\mathrm{D}}$ values were determined by fitting the observed sensorgrams using a two-state reaction model. The rS100A12, nS100A12, and fluorescein-labeled rS100A12 showed binding to CD36 (Fig. 3a, b). The affinities of rS100A12 (batch \#1: $K_{\mathrm{D}}=0.67 \pm 0.17 \mathrm{nM}$; batch $\left.\# 2: K_{\mathrm{D}}=0.99 \pm 0.33 \mathrm{nM}\right)$ and commercially available nS100A12 (batch \#1: $K_{\mathrm{D}}=1.04 \pm 0.50 \mathrm{nM}$; batch \#2: $K_{\mathrm{D}}=0.90 \pm 0.22 \mathrm{nM}$ ) to CD36 did not differ significantly and were determined to be close to $1 \mathrm{nM}$. In comparison, fluorescein-labeled rS100A12 showed a weaker binding affinity $\left(K_{\mathrm{D}}=4.79 \pm 0.38 \mathrm{nM}\right)$ to $\mathrm{CD} 36$.
Fig. 1 CD36 and RAGE expression. a Immunocytochemistry of CHO-K1, CHOCD36 and CHO-RAGE cells using anti-CD36 (green) and anti-RAGE (red) specific antibodies. b Western blot analyses of CHO-K1, CHO-CD36 and CHO-RAGE cell lysates using anti-CD36 and anti-RAGE specific antibodies

a
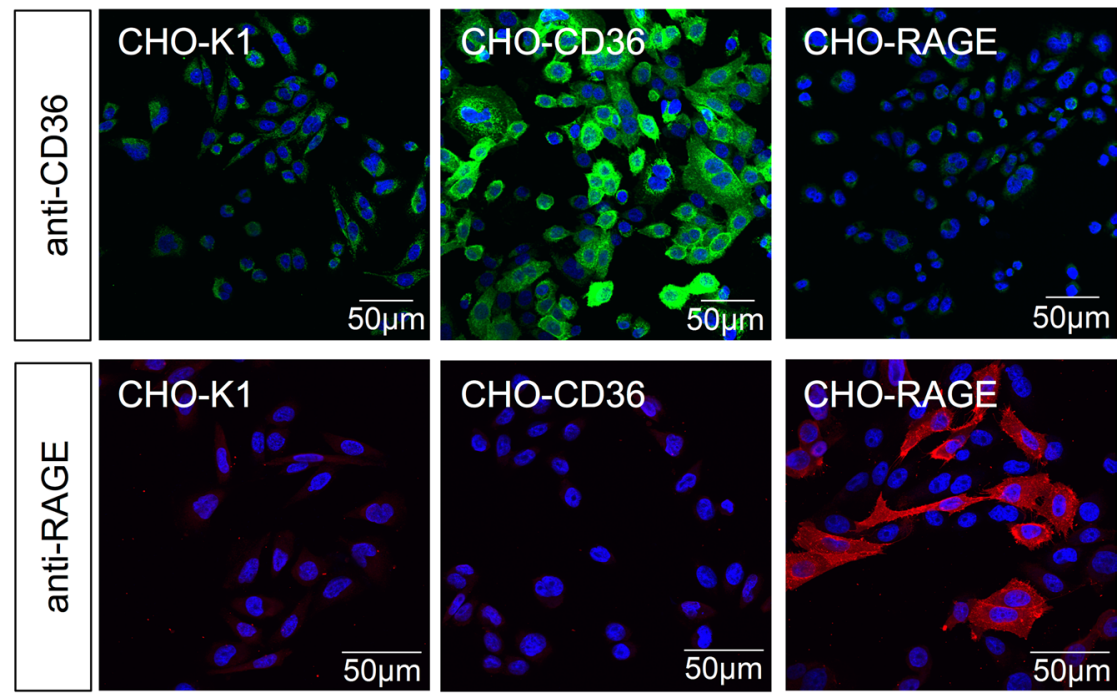

b

CD36 (88 kDa)

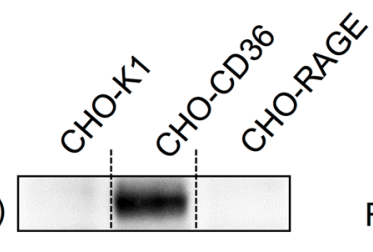

$\beta$-Actin (42 kDa)

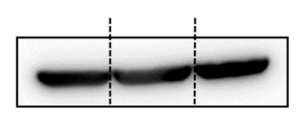

RAGE (52 kDa)

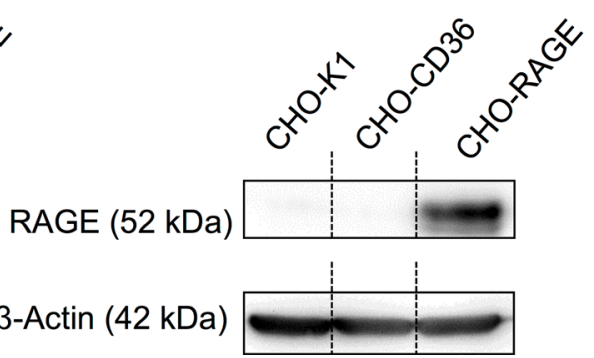

$\beta$-Actin (42 kDa) 
Fig. 2 Cell binding of labeled rS100A12. Cell binding experiments with a $\left[{ }^{18} \mathrm{~F}\right] \mathrm{FB}-\mathrm{rS} 100 \mathrm{~A} 12$ and $\mathbf{b}$ fluorescein-labeled rS100A12 were performed at $37{ }^{\circ} \mathrm{C}$ in $\mathrm{CHO}-\mathrm{K} 1$ cells, $\mathrm{CHO}-$ CD36 cells, CHO-CD36 cells blocked with anti-CD36 antibody (and in case of a excess of unlabeled rS100A12), and CHO-RAGE cells. $(n=6-12$, $*<0.05, * * p<0.01)$
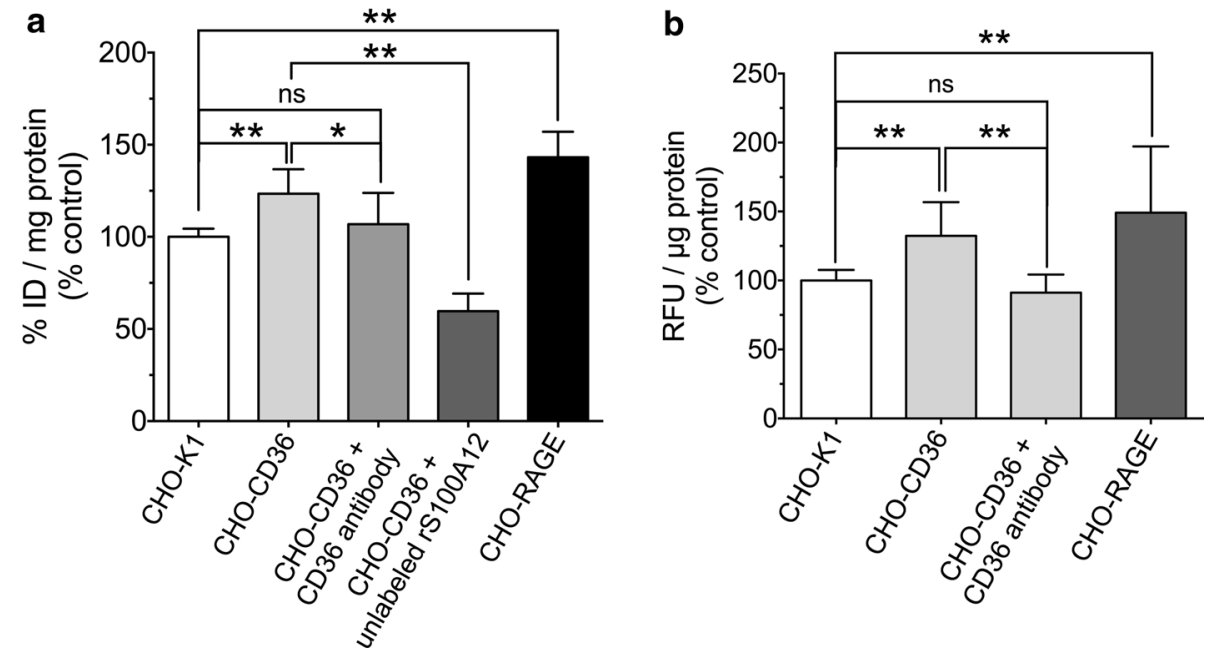

\section{Cell activation experiments}

Although S100A12 showed high affinity to CD36, activation of proteins that interact directly with $\mathrm{CD} 36$ or are activated by the CD36 signaling cascade (Fyn, pFyn, Lyn, pLyn, p38) could not be observed in CHO-K1, CHO-CD36, and CHO-RAGE cells by immunoblotting (Fig. S2a-e). However, incubation of CD36-positive $\mathrm{CHO}$ cells with rS100A12 lead to the recruitment of CD36, which normally is diffusely distributed in vesicles, to the cell surface (Fig. 4a, b). On the other hand, the incubation of CHO-K1,
CHO-CD36, and CHO-RAGE cells with rS100A12 lead to an increased synthesis of CD36 itself (Figs. 4c, S1b). This can be seen especially in CHO-K1 and CHO-RAGE cell lines that have low expression of CD36 under baseline conditions as already described above. Additionally, an upregulation of the PPAR $\gamma$ synthesis of all cell lines could be observed in preliminary studies (Fig. 4d). Therefore, potential regulatory mechanisms based on binding of S100A12 to CD36, and subsequently, leading to both higher recruitment of CD36 to the cell membranes and an elevation of CD36 synthesis could be hypothesized.
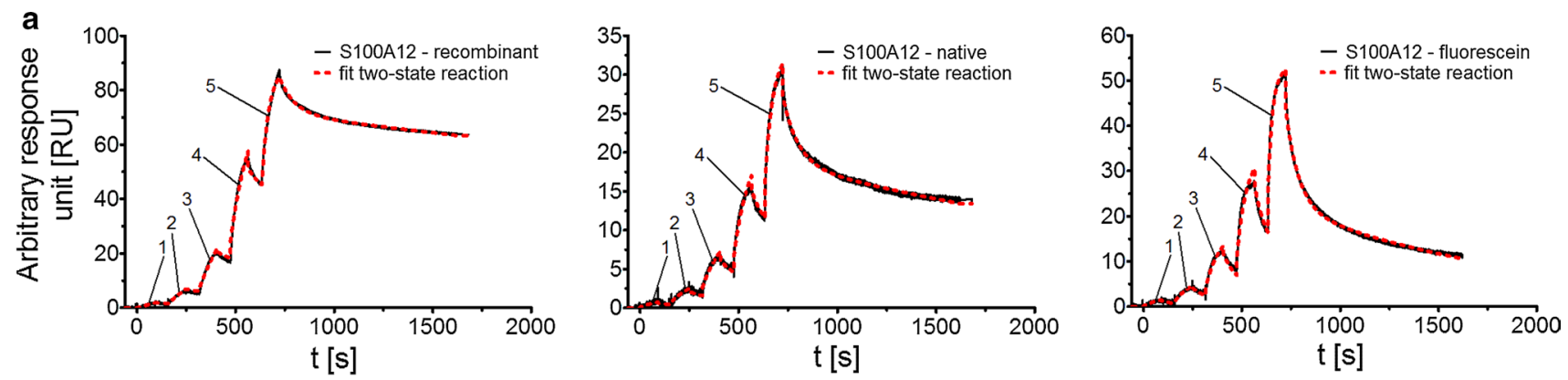

b

\begin{tabular}{c|ccccc|c}
\hline & $\mathbf{n}$ & $\boldsymbol{k}_{\mathrm{a}} \mathbf{1}(\mathbf{1} / \mathrm{Ms})$ & $\boldsymbol{k}_{\mathrm{d}} \mathbf{1}(\mathbf{1} / \mathbf{s})$ & $\boldsymbol{k}_{\mathrm{a}} \mathbf{2}(\mathbf{1} / \mathbf{s})$ & $\boldsymbol{k}_{\mathrm{d}} \mathbf{2}(\mathbf{1} / \mathbf{s})$ & $\mathbf{K}_{\mathrm{b}}[\mathrm{nM}] \pm \mathbf{S D}$ \\
\hline S100A12 recombinant 1 & 15 & $3.9 \cdot 10^{5}$ & $6.6 \cdot 10^{-3}$ & $9.5 \cdot 10^{-3}$ & $3.7 \cdot 10^{-4}$ & $0.67 \pm 0.17$ \\
S100A12 recombinant 2 & 8 & $3.1 \cdot 10^{5}$ & $1.9 \cdot 10^{-2}$ & $3.4 \cdot 10^{-3}$ & $6.8 \cdot 10^{-4}$ & $0.99 \pm 0.33$ \\
S100A12-native 1 & 18 & $1.2 \cdot 10^{6}$ & $8.3 \cdot 10^{-3}$ & $3.6 \cdot 10^{-3}$ & $5.1 \cdot 10^{-4}$ & $1.04 \pm 0.50$ \\
S100A12-native 2 & 9 & $1.2 \cdot 10^{6}$ & $9.2 \cdot 10^{-3}$ & $4.6 \cdot 10^{-3}$ & $5.6 \cdot 10^{-4}$ & $0.90 \pm 0.22$ \\
S100A12-fluorescein & 18 & $7.0 \cdot 10^{5}$ & $1.4 \cdot 10^{-2}$ & $3.2 \cdot 10^{-3}$ & $1.0 \cdot 10^{-3}$ & $4.79 \pm 0.38$ \\
\hline
\end{tabular}

Fig. 3 In vitro binding of S100A12 proteins to immobilized CD36. Surface plasmon resonance binding experiments of a rS100A12 (left), nS100A12 (middle), and fluorescein-labeled rS100A12 (right) to CD36 were performed. Results of representative experiments (subtracted sensorgrams) are shown. For evaluation of S100A12 binding kinetics, single-cycle kinetics was performed using concentrations ranging from 0.62 to $50.0 \mathrm{nM}(1-0.62,2-1.85,3-5.56,4-16.67$, 5-50 nM). Solid lines represent observed data; dotted lines indicate computer-derived fits as calculated by a two-state reaction model. In b the calculated $k_{a}, k_{d}$, and, $K_{D}$ values are shown. $(n=8-19)$ 
Fig. 4 rS100A12 stimulated CD36 translocation, CD36 expression, and PPAR $\gamma$ expression. Immunohistochemical staining of CHO-CD36 cells for CD36 (red) a before and b after incubation with $5 \mu \mathrm{M}$ of rS100A12, cell nuclei are stained with Hoechst 33258 (blue). Representative Western blot analysis of c CD36 synthesis $(n=5)$ and preliminary Western blot analysis of $\mathbf{d}$ PPAR $\gamma$ synthesis of CHO-K1, CHO-CD36, and CHO-RAGE cells without ( - ) and after activation (+) with $5 \mu \mathrm{M}$ of rS100A12 in calcium binding buffer for $90 \mathrm{~min}$ a

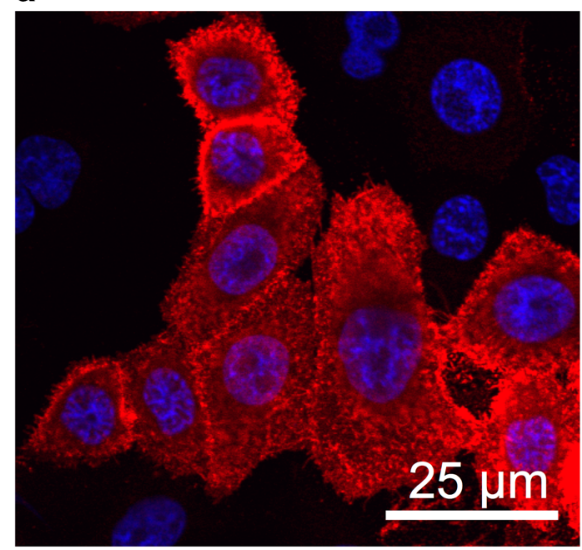

b

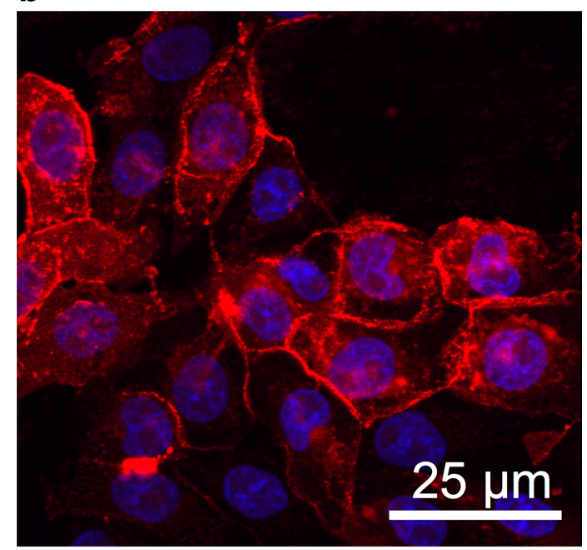

C

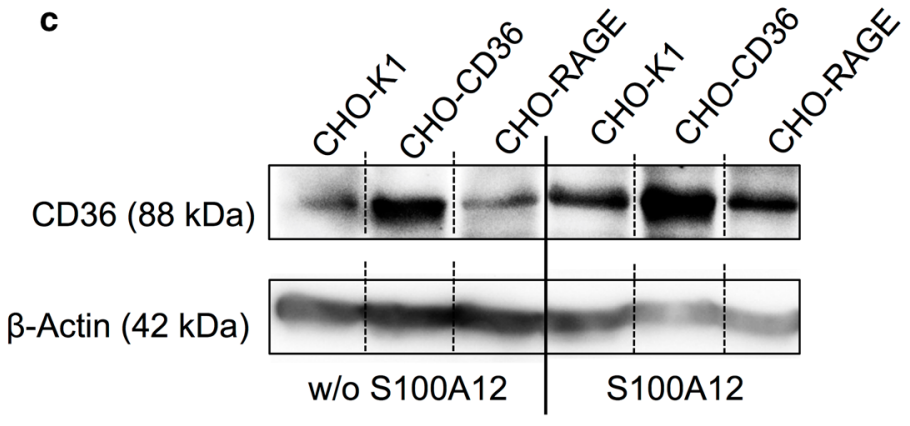

d

PPARY $(57 \mathrm{kDa})$

ß-Actin (42 kDa)

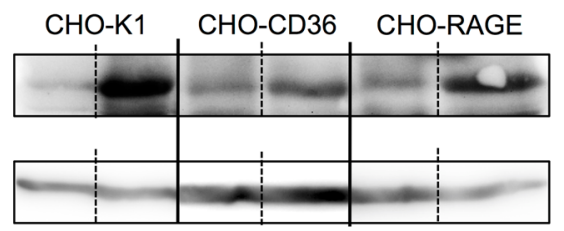

S100A12

\section{Discussion}

For the investigation of potential S100A12-CD36 binding, $\mathrm{CHO}$ cell lines were used. Immunoblotting and immunocytochemical analyses revealed that the $\mathrm{CHO}-\mathrm{K} 1$ cell line is a good negative control exhibiting no synthesis of RAGE and only low synthesis CD36. On the other hand, CHO-CD36 cells and CHO-RAGE cells show a high synthesis of CD36 and RAGE, respectively, without or with low synthesis of the respective other receptor. This study substantiates our former hypothesis on binding of S100A12 to members of the scavenger receptor family (Hoppmann et al. 2010) and first demonstrated class B scavenger receptor CD36 involved in high-affinity binding of S100A12. Cell binding experiments using both $\left[{ }^{18} \mathrm{~F}\right]$ fluorobenzoylated and fluorescein-labeled rS100A12 showed that S100A12 specifically binds to cells expressing CD36. Similarly, although in a higher amount, $\left[{ }^{18} \mathrm{~F}\right] \mathrm{FB}-\mathrm{rS} 100 \mathrm{~A} 12$ binds to cells expressing RAGE, a well-characterized receptor of S100A12. Blocking with a CD36-specific monoclonal antibody
[FA6-152] that specifically blocks the collagen and thrombospondin binding sites of CD36 (Doebele et al. 2009), revealed that S100A12 most likely shares the same binding site as thrombospondin or collagen and that the binding is specific (Silverstein and Febbraio 2009). Importantly, it has been described that this binding site is not identical to the fatty acid binding site of CD36, which is important for its function as fatty acid transporter (Silverstein and Febbraio 2009). The in vitro cell binding experiments were confirmed by SPR analyses. The latter revealed subnanomolar to low nanomolar binding affinities for unlabeled $\mathrm{r} / \mathrm{nS100A} 12$ and fluorescein-labeled rS100A12 to CD36.

Interestingly, the incubation of the different $\mathrm{CHO}$ cells with rS100A12 led to the recruitment of CD36 to the cell membranes. CD36 membrane recruitment is known to be regulated also by other stimuli like insulin (Samovski et al. 2012). Incubation of the CHO cells with S100A12 also leads to an increase of CD36 synthesis. This effect is even more striking looking at the less CD36 expressing cells like CHO-K1 and CHO-RAGE. Even though this effect 
could be due to the autoregulation of CD36 it could also be caused by the binding of S100A12 to RAGE (Xanthis et al. 2009). This would explain the high up-regulation of CD36 in CHO-RAGE cells but not for the RAGE-negative CHO-K1 and CHO-CD36 cells. This finding leads to the presumption that S100A12 could activate PPAR $\gamma$ through increased import of bioactive lipids (Ahmadian et al. 2013) through a not completely understood pathway (Silverstein 2009), which is consecutively increased by the membrane recruitment and the increase of CD36 synthesis (Tontonoz et al. 1998). The activation of PPAR $\gamma$ could also be seen in the higher protein synthesis of the protein itself.

Our results confirm that S100A12 shares the same binding site on CD36 as thrombospondin-1/-2 and collagen between amino acids 93 and 120 of CD36 (Doebele et al. 2009; Silverstein and Febbraio 2009). Oxidized LDL, on the other hand, has another binding site at the CD36 protein (Silverstein and Febbraio 2009). This is likely to support the hypothesis that the observed interaction of S100A12 and CD36, the subsequent recruitment of CD36 to the membrane, and the upregulation in CD36 synthesis, could be involved in translocation of fatty acids and regulation of PPAR $\gamma$ (Kopprasch et al. 2004; Graessler et al. 2007; Silverstein and Febbraio 2009). But to prove this hypothesis, further investigations have to be carried out. Another hypothesis that could be deduced from our data will attribute participation of CD36 in forming clusters of various pattern recognition receptors, including RAGE and/or Toll-like receptors (Drage et al. 2009; Jimenez-Dalmaroni et al. 2009; Xanthis et al. 2009; Jones et al. 2013). Here, CD36 could contribute exclusively to high-affinity binding of S10012 without activation of CD36-specific downstream signaling, but activation of signaling pathways downstream the suspected individual co-receptors. A future challenge will be the experimental differentiation of the conceivable, often highly redundant pathways (Lin 2006).

\section{Concluding remarks}

Taken together this study revealed S100A12 as potent binding partner of the class-B scavenger receptor/fatty acid translocase CD36. Binding could be observed by cell association experiments of labeled S100A12. SPR confirmed the binding revealing affinities in the low nanomolar range. A recruitment of CD36 to the surface of the CHO-CD36 cells could be observed, which suggest a regulatory function of S100A12 for the lipid transport by direct interaction with CD36.

\footnotetext{
Acknowledgments The authors are grateful to Mareike Barth, Catharina Heinig, Uta Lenkeit, and Aline Morgenegg for their expert technical assistance in preparation of recombinant S100A12, radiosynthesis of $\left[{ }^{18} \mathrm{~F}\right] \mathrm{SFB}$, and radiolabeling of S100A12. We are also grateful to Susan Hoppmann, Ph.D., for establishment of the CHO-RAGE cells.
}

The authors also thank Hannes Brinkmann, M.Sc., for performing cell association experiments, which were part of his master thesis at the Technische Universität Dresden, Department of Chemistry and Food Chemistry. This work was supported in part by the German Research Foundation (Grant Pi 304/1-1).

\section{Compliance with ethical standards}

Conflict of interest The authors declare no competing financial interests.

Open Access This article is distributed under the terms of the Creative Commons Attribution 4.0 International License (http://creativecommons.org/licenses/by/4.0/), which permits unrestricted use, distribution, and reproduction in any medium, provided you give appropriate credit to the original author(s) and the source, provide a link to the Creative Commons license, and indicate if changes were made.

\section{References}

Acton SL, Scherer PE, Lodish HF, Krieger M (1994) Expression cloning of SR-BI, a CD36-related class B scavenger receptor. J Biol Chem 269:21003-21009

Adachi H, Tsujimoto M (2006) Endothelial scavenger receptors. Prog Lipid Res 45:379-404

Ahmadian M, Suh JM, Hah N et al (2013) PPAR $\gamma$ signaling and metabolism: the good, the bad and the future. Nat Med 19:557-566

Doebele RC, Schulze-Hoepfner FT, Hong J et al (2009) A novel interplay between Epac/Rap1 and mitogen-activated protein kinase 5/ extracellular signal-regulated kinase 5 (MEK5/ERK5) regulates thrombospondin to control angiogenesis. Blood 114:4592-4600

Donato R, Cannon BR, Sorci G et al (2013) Functions of S100 proteins. Curr Mol Med 13:24-57

Drage MG, Pecora ND, Hise AG et al (2009) TLR2 and its co-receptors determine responses of macrophages and dendritic cells to lipoproteins of Mycobacterium tuberculosis. Cell Immunol 258:29-37

Fritz G (2011) RAGE: a single receptor fits multiple ligands. Trends Biochem Sci 36:625-632

Fyrnys B, Claus R, Wolf G, Deigner HP (1997) Oxidized low density lipoprotein stimulates protein kinase $\mathrm{C}(\mathrm{PKC})$ activity and expression of $\mathrm{PKC}$-isotypes via prostaglandin-H-synthase in P388D1 cells. Adv Exp Med Biol 407:93-98

Gao D, Ashraf MZ, Kar NS et al (2010) Structural basis for the recognition of oxidized phospholipids in oxidized low density lipoproteins by class B scavenger receptors CD36 and SR-BI. J Biol Chem 285:4447-4454

Goyette J, Yan WX, Yamen E et al (2009) Pleiotropic roles of S100A12 in coronary atherosclerotic plaque formation and rupture. J Immunol 183:593-603

Graessler J, Pietzsch J, Westendorf T et al (2007) Glycoxidised LDL isolated from subjects with impaired glucose tolerance increases CD36 and peroxisome proliferator-activator receptor gamma gene expression in macrophages. Diabetologia 50:1080-1088

Hatakeyama T, Okada M, Shimamoto S et al (2004) Identification of intracellular target proteins of the calcium-signaling protein S100A12. Eur J Biochem 271:3765-3775

Hofmann MA, Drury S, Fu C et al (1999) RAGE mediates a novel proinflammatory axis: a central cell surface receptor for S100/ calgranulin polypeptides. Cell 97:889-901

Hoppmann S, Haase C, Richter S, Pietzsch J (2008) Expression, purification and fluorine-18 radiolabeling of recombinant S100 
proteins-potential probes for molecular imaging of receptor for advanced glycation endproducts (RAGE) in vivo. Protein Expr Purif 57:143-152

Hoppmann S, Steinbach J, Pietzsch J (2010) Scavenger receptors are associated with cellular interactions of S100A12 in vitro and in vivo. Int J Biochem Cell Biol 42:651-661

Hsu H-Y, Chiu S-L, Wen M-H et al (2001) Ligands of macrophage scavenger receptor induce cytokine expression via differential modulation of protein kinase signaling pathways. J Biol Chem 276:28719-28730

Jimenez-Dalmaroni MJ, Xiao N, Corper AL et al (2009) Soluble CD36 ectodomain binds negatively charged diacylglycerol ligands and acts as a co-receptor for TLR2. PLoS One 4(10): 7411

Jones RS, Minogue AM, Connor TJ, Lynch MA (2013) Amyloid- $\beta$ induced astrocytic phagocytosis is mediated by CD36, CD47 and RAGE. J Neuroimmune Pharmacol 8:301-311

Koonen DPY, Glatz JFC, Bonen A, Luiken JJFP (2005) Long-chain fatty acid uptake and FAT/CD36 translocation in heart and skeletal muscle. Biochim Biophys Acta 1736:163-180

Kopprasch S, Pietzsch J, Westendorf T et al (2004) The pivotal role of scavenger receptor CD36 and phagocyte-derived oxidants in oxidized low density lipoprotein-induced adhesion to endothelial cells. Int J Biochem Cell Biol 36:460-471

Kosaki A, Hasegawa T, Kimura T et al (2004) Increased plasma S100A12 (EN-RAGE) levels in patients with type 2 diabetes. J Clin Endrocinol Metab 89:5423-5428

Leclerc E, Fritz G, Vetter SW, Heizmann CW (2009) Binding of S100 proteins to RAGE: an update. Biochim Biophys Acta 1793:993-1007

Lin L (2006) RAGE on the toll road? Cell Mol Immunol 3:351-358

Marsche G, Weigle B, Sattler W, Malle E (2007) Soluble RAGE blocks scavenger receptor CD36-mediated uptake of hypochlorite-modified low-density lipoprotein. FASEB J 21:3075-3082

Mehta JL, Li D (2002) Identification, regulation and function of a novel lectin-like oxidized low-density lipoprotein receptor. J Am Coll Cardiol 39:1429-1435

Mikkelsen SE, Novitskaya V, Kriajevska M et al (2001) S100A12 protein is a strong inducer of neurite outgrowth from primary hippocampal neurons. J Neurochem 79:767-776

Mori Y, Kosaki A, Kishimoto N et al (2009) Increased plasma S100A12 (EN-RAGE) levels in hemodialysis patients with atherosclerosis. Am J Nephrol 29:18-24

Ohgami N, Nagai R, Ikemoto M et al (2001) CD36, a member of the class B scavenger receptor family, as a receptor for advanced glycation end products. Ann N Y Acad Sci 947:350-355

Olivetta E, Tirelli V, Chiozzini C et al (2014) HIV-1 Nef impairs key functional activities in human macrophages through CD36 downregulation. PLoS One 9:e93699

Park YM (2014) CD36, a scavenger receptor implicated in atherosclerosis. Exp Mol Med 46:e99

Pietzsch J, Hoppmann S (2009) Human S100A12: a novel key player in inflammation? Amino Acids 36:381-389
Platt N, Suzuki H, Kurihara Y et al (1996) Role for the class A macrophage scavenger receptor in the phagocytosis of apoptotic thymocytes in vitro. Proc Natl Acad Sci USA 93:12456-12460

Salama I, Malone PS, Mihaimeed F, Jones JL (2008) A review of the S100 proteins in cancer. Eur J Surg Oncol 34:357-364

Samovski D, Su X, Xu Y et al (2012) Insulin and AMPK regulate FA translocase/CD36 plasma membrane recruitment in cardiomyocytes via Rab GAP AS160 and Rab8a Rab GTPase. J Lipid Res 53:709-717

Sawamura T, Kakutani M, Mingyi C, Masaki T (2000) LOX-1, an endothelial receptor for oxidized LDL Implications for induction of endothelium dysfunction in the pathogenesis of vascular diseases. In: Kita T, Yokode M (eds) Lipoprotein metabolism and atherogenesis. Springer-Verlag, Tokyo, pp 193-198

Silverstein RL (2009) Inflammation, atherosclerosis, and arterial thrombosis: role of the scavenger receptor CD36. Cleve Clin J Med 76(Suppl 2):S27-S30

Silverstein RL, Febbraio M (2009) CD36, a scavenger receptor involved in immunity, metabolism, angiogenesis, and behavior. Sci Signal 2:re3

Thelen T, Hao Y, Medeiros AI et al (2010) The class A scavenger receptor, macrophage receptor with collagenous structure, is the major phagocytic receptor for Clostridium sordellii expressed by human decidual macrophages. J Immunol 185:4328-4335

Tontonoz P, Nagy L, Alvarez JGA et al (1998) PPAR $\gamma$ promotes monocyte/macrophage differentiation and uptake of oxidized LDL. Cell 93:241-252

Vog1 T, Pröpper C, Hartmann M et al (1999) S100A12 is expressed exclusively by granulocytes and acts independently from MRP8 and MRP14. J Biol Chem 274:25291-25296

Wang Y, Fang C, Gao H et al (2014) Platelet-derived S100 family member myeloid-related protein-14 regulates thrombosis. J Clin Invest 124:2160-2171

Wolf S, Haase-Kohn C, Lenk J et al (2011) Expression, purification and fluorine-18 radiolabeling of recombinant S100A4: a potential probe for molecular imaging of receptor for advanced glycation endproducts in vivo? Amino Acids 41:809-820

Xanthis A, Hatzitolios A, Fidani S et al (2009) Receptor of advanced glycation end products (RAGE) positively regulates CD36 expression and reactive oxygen species production in human monocytes in diabetes. Angiology 60:772-779

Yan WX, Armishaw C, Goyette J et al (2008) Mast cell and monocyte recruitment by S100A12 and its hinge domain. J Biol Chem 283:13035-13043

Yang Z, Tao T, Raftery MJ et al (2001) Proinflammatory properties of the human S100 protein S100A12. J Leukoc Biol 69:986-994

Yang Z, Yan X, Cai H et al (2007) S100A12 provokes mast cell activation: a potential amplification pathway in asthma and innate immunity. J Allergy Clin Immunol 119:106-114

Yu H, Ha T, Liu L et al (2012) Scavenger receptor A (SR-A) is required for LPS-induced TLR4 mediated NF- $\mathrm{KB}$ activation in macrophages. Biochim Biophys Acta 1823:1192-1198 